УДК 929+903.27

DOI 10.25205/978-5-4437-1268-0-84-89

A. V. Varenov

Novosibirsk State University, Novosibirsk, Russia

\title{
LIFE AND WORKS OF GAI SHANLIN (1935-2020) - A PROMINENT CHINESE ROCK ART RESEARCHER
}

Gai Shanlin (盖山林), of Manchu origin, was a native of Xingtang County, Hebei Province in China. He was born on 10 September 1935, and received higher education in Xian city in 1960. Since 1962, Gai Shanlin was employed at the Inner Mongolian Archaeology of Cultural Heritage Research Institute. He was a prominent rock art researcher, considered to be No. 1 in China. Gai Shanlin was the first who discovered, described and published materials of the rock art sites of Inner Mongolia in the Yinshan mountains, the Wulanchabu grassland and the Badain Jaran Desert. During his life, he wrote about a dozen books and several hundred articles on the subject. Since 1988, Gai Shanlin was also a member of the China Association for Promoting Democracy. He was elected Vice-Chairman of the 9th CPPCC Inner Mongolia Autonomous Regional Committee in 2003 and held that post until 2008. Gai Shanlin aged 85 passed away on 9 February 2020, in Hoh-hot city.

Key words: Gai Shanlin, biography, rock art of China, petroglyphs of Inner Mongolia, Yinshan, Wulanchabu, Badain Jaran, problems of dating and semantics

\section{А. В. Варенов}

Новосибирскоий государственный университет, Новосибирск, Россия

\section{ЖИЗНЬ И ТВОРЧЕСТВО ГАЙ ШАНЬЛИНЯ (1935-2020) - выдающегося китайского исследователя наскального искусства}

Гай Шаньлинь (盖山林), маньчжур по нацинальности, родился 10 сентября 1935 г. в уезде Синтан провинции Хэбэй. После окончания Северо-Западного университета в г. Сиань по специальности археология Гай Шаньлинь работал заведующим отделом истории в краеведческом музее Нинся-Хуэйского автономного района. В апреле 1962 г. он перешел на работу в Институт археологии и материальной культуры Автономного района Внутренняя Монголия, где активно занимался разведками и раскопками археологических памятников. В числе наиболее значимых результатов этих работ - монография «Настенные росписи Ханьских гробниц Хэлиньгээра» (1978). Кроме того, Гай Шаньлинь изучал археологию и этническую историю племени онгутов, результатом чего стала монография «Онгуты Иньшаня» (1991). Гай Шаньлинь оказался первым китайским ученым, проводившим целенаправленные и систематические поиски и исследования наскальных изображений. В числе его наиболее значительных работ, посвященных публикации памятников наскального искусства, монографии «Петроглифы (гор) Иньшань» (1986), «Петрог-

(c) A. V. Varenov, 2021 
лифы (степи) Уланьчаб» (1989) и «Петроглифы пустыни Баданьцзилинь» (1997). Из ранних исследований теоретического характера можно отметить «Петроглифы Иньшань» (1985) - книгу, одноименную с публикационной монографией 1986 г. В 1995 г. вышли собрание многочисленных статей Гай Шаньлиня и «Китайское петроглифоведение», а в 1997 г. - научно-популярные «Петроглифы Китая». В 2002 г. увидела свет фундаментальная монография «Дешифровка культуры петроглифов Внутренней Монголии», написанная ученым в соавторстве с сыном Гай Чжихао. Гай Шаньлинь вышел на пенсию в 2009 г. и скончался в г. Хух-Хото 9 февраля 2020 г. на 85-м году жизни.

Key words: Гай Шаньлинь, биография, наскальное искусство Китая, петроглифы Внутренней Монголии, Иньшкнь, Уланчаб, Бадын Джаран, проблемы датировки и семантики

Gai Shanlin (盖山林) of Manchu descent, was born on 10 $0^{\text {th }}$ September 1935 in Xingtang County, Hebei Province (fig. 1, 1). After successfully graduating from school, Gai Shanlin worked at the Lanzhou branch of the People's Bank of China from March to July 1956. However, a career in banking was not for Gai Shanlin. From August 1956 to September 1960 he studied archaeology in the History Department of Northwest University in Xian. After his graduation, Gai Shanlin served at the Museum of the Ningxia Hui Autonomous Region in Yinchuan as the head of the Historical Department between September 1960 and April $1962^{1}$.

In 1962, he transferred to Inner Mongolia to continue his archaeological career. In April 1962, Gai Shanlin started working at the Institute of Cultural Relics and Archaeology of the Inner Mongolia Autonomous Region. After his transfer to Hohhot, Gai Shanlin was very active in the search and excavations of Inner Mongolian archaeological sites. Among the most notable results of these activities was his book "The Mural Paintings of the Han Tombs of Helingeer" [Gai Shanlin, 1978] (fig. 1, 3).

As a result of his research in the 1970s, Gai Shanlin made a name for himself among western archaeologists as one of the first (post-1949) and most prominent explorers of Nestorian antiquities in Inner Mongolia, discovering quite a number of new sites. The search for traces of Nestorianism in Inner Mongolia however was not the primary aim for Gai Shanlin, since at the time he was focused on studying the archaeology and ethnical history of the Wanggu tribe, which resulted in his book titled "Yinshan Wanggu" [Gai Shanlin, 1991] (fig. 1, 4).

One time when Gai Shanlin was a student, his teacher was discussing European rock paintings and grottoes, adding that there is no rock art in China. However, Gai Shanlin was not convinced; how could a country as big as China not has such a phenomenon? And could it really be true, or has rock art in China simply never been discovered to date? Gai Shanlin found out that Li Daoyuan (婯道元 472-527), the famous medieval geographer of the Northern Wei Dynasty, who lived in the 5th-6th centuries $\mathrm{AD}$, mentioned 22 rock art sites in his "Shui Jing Zhu” treatise.

The investigation and research of rock paintings in China began in 1927 when Professor Huang Zhongqin of Lingnan University investigated petroglyphs of Xianxuetan in Taixi, Hua'an County, Fujian Province. However, Gai Shanlin was the first person to conduct scientific and systematic Chinese rock art investigation and research.

In 1976, the Institute assigned him to visit the Great Wall of Urad Rear Banner in the northern part of Bayannaoer League (now Bayannaoer City), passing through the Wujiahe Township of Urad Middle Banner, where there were petroglyphs, recorded in Li Daoyuan's writings. Under the guidance of local Mongolian young people, Gai Shanlin found and saw animal images carved on rocks. This marked the beginning of Gai Shanlin's quest for rock art (fig. 1,2).

\footnotetext{
${ }^{1}$ Подробнее на русском языке о жизни и деятельности Гай Шаньлиня см. [Варенов, 2020].
} 
From 1976 to 1980, Gai Shanlin would travel to the Langshan mountain range area of the Yinshan Mountains in the southern part of Inner Mongolia to inspect the rock art sites of the Yinshan Mountains. The total length of this journey reached more than 12,000 kilometers. Gai Shanlin discovered about 10 thousand images and copied more than 1,500 of them.

From 1980 to 1983, Gai Shanlin inspected the rock art in the Ulanchab grassland to the north of the Yinshan Mountains. The inspection range also covered hundreds of miles, and the number of rock paintings found was similar to that of the Yinshan Mountains. At the same time, Gai Shanlin also inspected petroglyphs of the Table Mountains (Zhuozishan) in Wuhai City region at the northern end of the Helan Mountains.

In 1987, Gai Shanlin inspected the rock art of Alxa League in the Badain Jaran Desert in the western part of Inner Mongolia and copied more than 1,000 petroglyphs. In the same year, he was invited by the Zhangzhou Municipal Bureau of Culture in Fujian Province to inspect the rock art of Hua'an, Zhangpu, and Longhai counties in southern Fujian.

Gai Shanlin also visited petroglyphs of Jiangjun Cliff in Lianyungang County, Jiangsu Province and rock paintings in the four counties of Guangxi: Ningming, Chongzuo, Fusui, and Longzhou in the Mingjiang and Zuojiang River basins. While abroad in 1989, Gai Shanlin visited petroglyphs in Texas and Colorado in the USA and the southern Alberta Province in Canada. From these inspections and visits, he gradually mastered the methods of inspection, and realized their functions and significance.

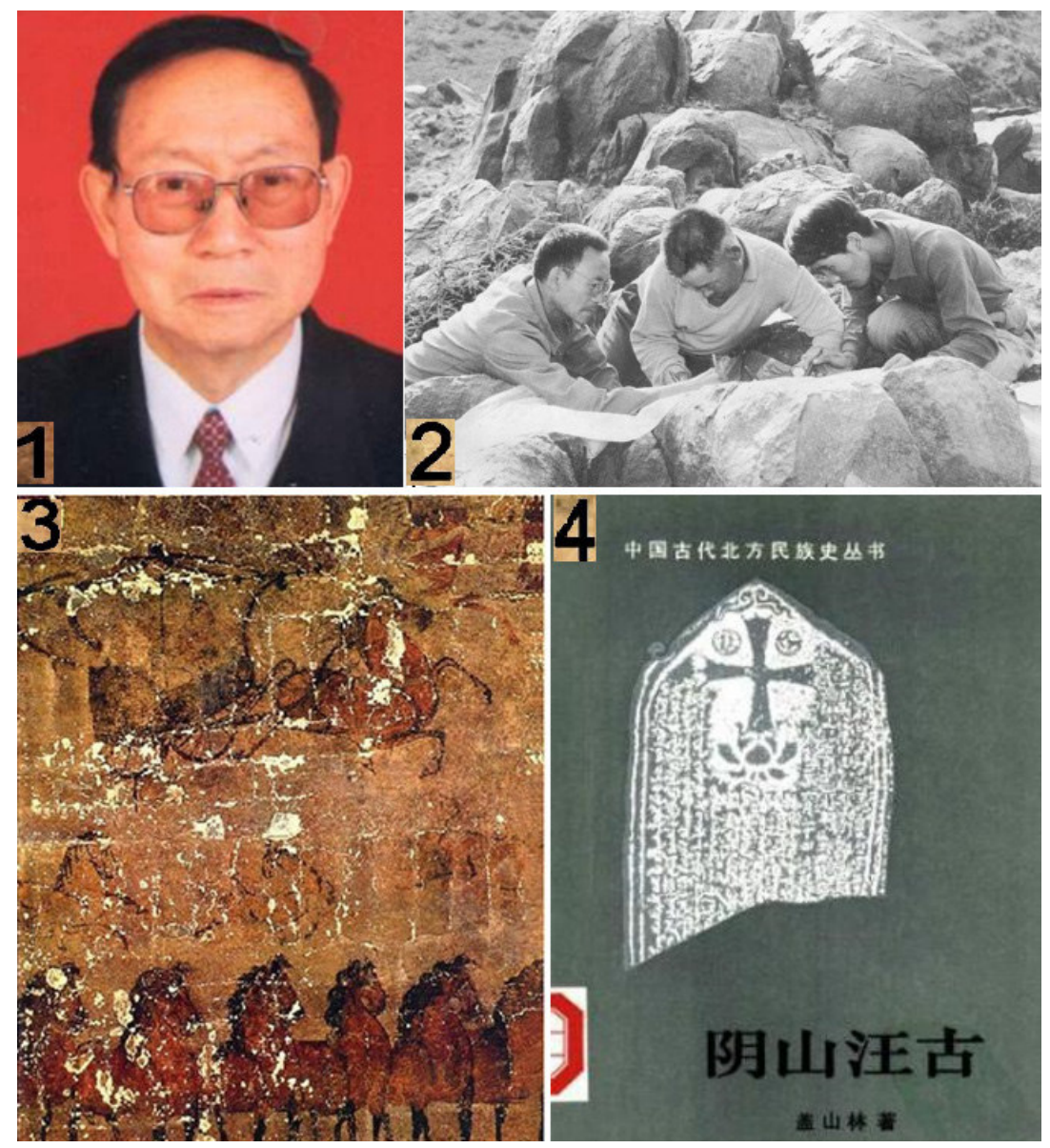

Fig. 1. Gai Shanlin and his books: 7 - Gai Shanlin (1935-2020), 2 - Gai Shanlin (at the left) at Yinshan mountains with the locals copying petroglyphs, 3 - «The Mural Paintings of the Han Tombs of Helingeer» (1978), 4 - «Yinshan Wanggu» (1991). All are scanned by the author 
Among the most significant books by Gai Shanlin devoted to the description of rock art sites of different regions of Inner Mongolia are "Petroglyphs in the Yinshan Mountains” [Gai Shanlin, 1986] (fig. 2, 1), "Petroglyphs in the Wulanchabu Grassland" [Gai Shanlin, 1989] (fig. 2, 2) and "The Rock Art in Badanjilin Desert" [Gai Shanlin, 1997a] (fig. 2, 3). Among the early theoretical research works one can note "Petroglyphs in the Yinshan Mountains" [Gai Shanlin, 1985] (fig. 3, 1) - the book with the same title as the publication of rock art sites of 1986, but completely devoted to interpretations of rock art ${ }^{2}$.

After being assigned an administrative post at the Institute of Cultural Relics and Archaeology of the Inner Mongolia Autonomous Region at the end of 1987, Gai Shanlin stopped his long expeditions in search of new rock art sites, perhaps because of his new duties or due to old age. Nevertheless Gai Shanlin continued to publish both serious theoretical books and popular editions devoted to rock art research. Among the former are the collection of numerous articles by Gai Shanlin, originally published in journals that were hard to get [Gai Shanlin, 1995a] (fig. 3, 2) and "Chinese Petroglyphic Studies" [Gai Shanlin, 1995b] (fig. 3, 3), and the latter - "Chinese Petroglyphs" [Gai Shanlin, 1997b] (fig. 3, 4).

In 2002, as if summing up this period of his life, Gai Shanlin published a fundamental book written in co-authorship with his son Gai Zhihao "Deciphering the Culture of Petroglyphs of Inner Mongolia" [Gai Shanlin, 2002] (fig. 2, 4). All this time, Gai Shanlin was taking part in scientific activities, visiting international academic conferences devoted to rock art research and presenting papers that were always met with keen interest.

Toward the end of his life, Gai Shanlin devoted his time to political and social activities. He joined the China Association for the Promotion of Democracy (中国民主促进会 - one of eight “small” parties legally acting in the PRC - allies of the Communist Party of China) in August 1988. After retiring from the post of Vice-Director of the Institute of Cultural Relics and Archaeology of Inner Mongolia at the age of 60 in 1996, Gai Shanlin became more active in the China Association for the Promotion of Democracy.

\footnotetext{
${ }^{2}$ Подробнее на русском языке о посвященных петроглифам книгах Гай Шаньлиня см. [Варенов,
} 2021]. 


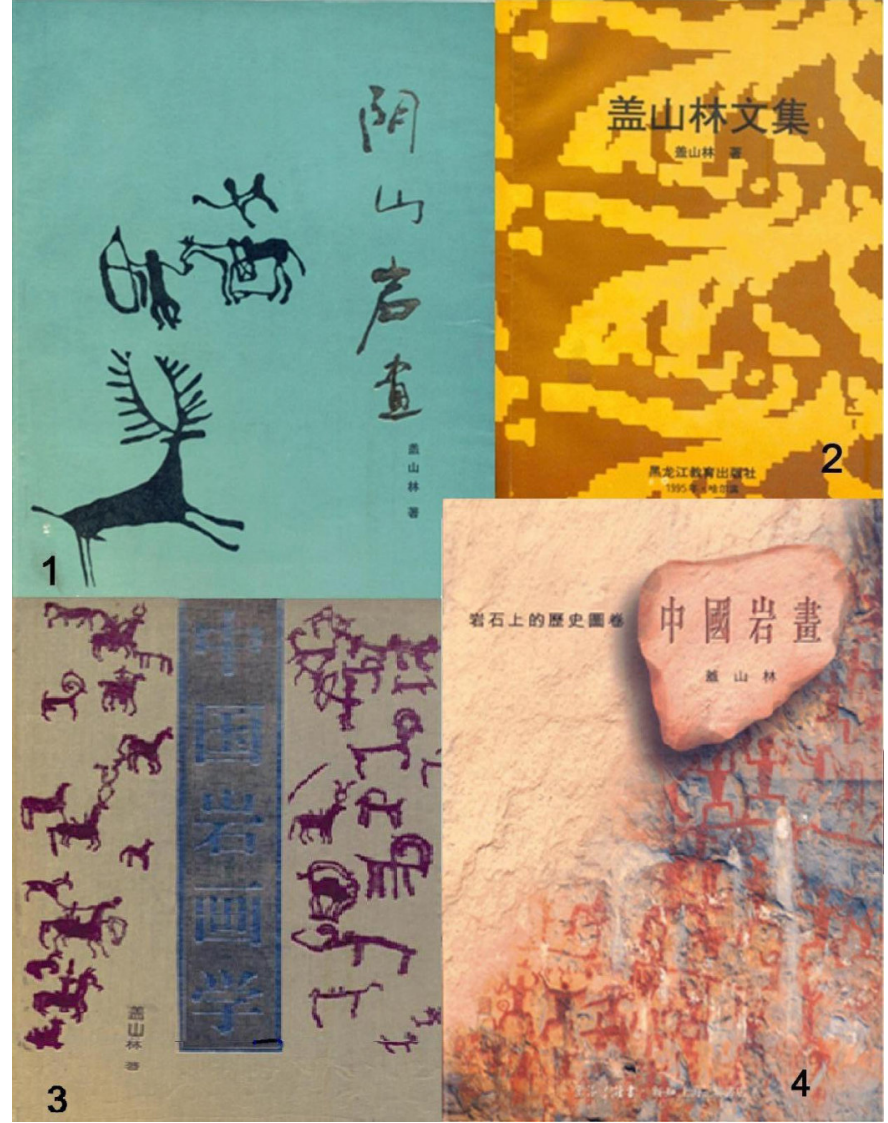

Fig. 3. Books by Gai Shanlin: 7 - «Petroglyphs in the Yinshan Mountains» (1985), 2 - «Collection of articles by Gai Shanlin» (1995), 3 - «Chinese rock art science» (1995), 4 - «History scroll on the rocks - Chinese petroglyphs» (1997). All are scanned by the author
From 1998 to 2003, Gai Shanlin acted as the Chairman of the China Association for the Promotion of Democracy of the Inner Mongolia Autonomous Region, Vice Chairman of the 8th Chinese People's Political Consultative Conference (CPPCC) of the Inner Mongolia Autonomous Region, and Member of the Central Standing Committee of the China Association for the Promotion of Democracy. From 2003 to 2008, Gai Shanlin was again elected to serve as Vice Chairman of the 9th CPPCC of the Inner Mongolia Autonomous Region. He retired in July 2009. Gai Shanlin died of illness on $9^{\text {th }}$ February 2020 at the age of 85 in Hohhot.

\section{References}

Варенов А. В. Памяти Гай Шаньлиня (1935-2020) - выдающегося исследователя наскального искусства Китая // Вестник НГУ. Серия: История, филология. 2020. Т. 19, вып. 10: Востоковедение. - С. 162-166. DOI 10.2520 5/1818-7919-2020-19-10-162-166

Варенов А.В. Монографические публикации и исследования петроглифов северных районов Китая в последней четверти XX века // Вестник

НГУ. Серия: История, филология. 2021. Т. 20, № 4: Востоковедение. С. 37-52. DOI 10.2520 5/1818-7919-2021-20-4-37-52

Gai Shanlin. Helingeer Hanmu bihua [蓋山林。和林格尔汉墓壁画]. The Mural Paintings of the Han Tombs of Helingeer. Hoh-Hot, 1978. 102 p. ( $2^{\text {nd }}$ edition - 1986). (in Chin.)

Gai Shanlin. Yinshan yanhua [蓋山林。陰山岩画] Petroglyphs in the Yinshan Mountains. Huhehot, Nei Menggu renmin publishers, 1985. 4, 192 p. (in Chin.)

Gai Shanlin. Yinshan yanhua [蓋山林。陰山岩画]. Petroglyphs in the Yinshan Mountains. Beijing, Wenwu publishers, 1986. 2, 20, 442 p. (in Chin.)

Gai Shanlin. Wulanchabu yanhua [蓋山林。烏蘭察部岩画]. Petroglyphs in the Wulanchabu Grassland. Beijing, Wenwu publishers, 1989. 22, 336 p. (in Chin.)

Gai Shanlin. Yinshan Wanggu [蓋山林。阴山汪古]. Hoh-Hot, 1991. (Honkong edition 1995). 428 p. (in Chin.)

Gai Shanlin wenji [盖山林文集]. Collection of papers by Gai Shanlin. Haerbing, Heilongjiang jiaoyu publishers, 1995a. 916 p. (in Chin.)

Gai Shanlin. Zhongguo yanhuaxue [蓋山林。中国岩画学]. Chinese Petroglyphic Studies. Beijing, Shumu wenxian publishers, 1995b. 338 p., XVI pl. (in Chin.) 
Gai Shanlin. Badanjilin shamo yanhua [盖山林。巴丹吉林沙漠岩画]. Petroglyphs in Badanjilin Desert. Beijing, Beijing Tushuguan publishers, 1997a. 400 p. (in Chin.)

Gai Shanlin. Yanshi shangde lishi tujuan: Zhongguo yanhua [盖山林。岩石上的历史图卷:中 国岩画]. Illustrated Scrolls of History on the Rocks: Chinese Petroglyphs. Shanghai: Sanlian shudian publishers, 1997b. 126 p. (in Chin.)

Gai Shanlin, Gai Zhihao. Nei Menggu yanhua de wenhua jiedu [盖山林, 盖志浩。内蒙 古岩画的文化解读]. Deciphering the Culture of Petroglyphs of Inner Mongolia. Beijing, Beijing Tushuguan publishers, 2002. 546 p. (in Chin.) 